\title{
Prilaku Sosial Politik Tuan Guru Pasca Reiormasi Dalam Memajukan Pendidikan Islam Di Lombok
}

\author{
Udin \\ Dosen Pascasarjana UIN Mataram \\ msudin@uinmataram.ac.id
}

Abstract: This research aim to explore the political behavior of Tuan Guru in post-reformation in Lombok. This research also trie to reveal the existence of Tuan Guru in terms of the historical aspects of the cultural traditions and religious patterns of the Lombok society. This research found that Tuan Guru in Lombok has a very broad position and role, not only in the religious aspects, but also in the social, economic and political fields.

Keywords: Behavior, Master Teacher Politics, Advancing Education.

Abstrak: Penelitian ini menelusuri perilaku politik Tuan Guru di Lombok pasca reformasi, Penelitian ini juga berusaha mengungkapkan keberadaan Tuan Guru dilihat dari aspek historisitas tradisi budaya dan pola keberagamaan masyarakat Lombok, Penelitian ini menemukan hasil bahwa Tuan Guru di Lombok memiliki kedudukan dan peranan yang sangat luas, tidak hanya pada aspek keagamaan, melainkan juga pada bidang sosial, ekonomi dan politik.

Kata Kunci: Perilaku, Politik Tuan Guru, Memajukan Pendidikan. 


\section{Pendahuluan}

Dari sejarah sosio kultural, Tuan Guru memegang peranan penting dalam berbagai aspek baik aspek agama, sosial, budaya, dan politik. Ucapan yang keluar dari Tuan Guru mempunyai pengaruh yang kuat dalam masyarakat. Sedangkan kesetiaan yang diberikan oleh masyarakat bisa berupa ketundukan, penghormatan, dan kepatuhan. Tuan Guru di Lombok hadir sebagai sosok yang mempunyai pengetahuan dan lebih terhormat dibanding masyarakat kebanyakan lainnya. Tuan Guru menjadi sosok elit sosio kultural dalam masyarakat.

Sementara dalam tradisi kemasyarakatan di Lombok ditemukan bahwa sosok Tuan Guru adalah pemimpin yang penuh tanggungjawab, menyintai umatnya serta tahu betul kemana harus berjalan membawa umatnya. Tuan Guru dalam masyarakat Lombok diidentikkan dengan guru agama yang mengajar agama di tengah-tengah masyarakat dan memiliki kedudukan terhormat, berperanan penting dan strategis dalam kehidupan masyarakat. Seorang Tuan Guru dianggap memiliki kedalaman ilmu, spiritualitas tinggi, dan berakhlaqul karimah.

Seringkali Tuan Guru diposisikan sebagai pemimpin informal, yaitu tempat bertanya, mengadukan semua permasalahan yang tidak hanya persoalan keagamaan melainkan meluas pada problem ekonomi, sosial, politik dan lain-lain. Karena itu sosok Tuan Guru di Lombok selalu berhubungan dengan segala aspek kehidupan, baik aspek politik, sosial dan pendidikan, meskipun tidak secara langsung berpartisipasi aktif atau terlibat dalam sebuah partai politik

\section{Prilaku Soisal Politik Tuan Guru Pasca Reiormasi}

Era reformasi dengan cepatnya merubah perilaku Tuan Guru yang dulunya hanya sebagai pelaku politik pinggiran, bahkan ada yang hanya sebagai penonton, sekarang menjadi penguasa. Pergeseran perilaku Tuan Guru dalam percaturan politik tersebut tentu mengakibatkan perubahan dan peran yang harus dimainkan, hal ini tentu tidak mudah, butuh waktu untuk beradaptasi dan menjalankan pola dan bentuk yang sesuai dengan karakter moral Tuan Guru. Tuan Guru yang menduduki jabatan politis 
tentu harus mengikuti protokoler yang sudah berjalan, sebuah dilema tersendiri bagi Tuan Guru pesantren yang terbiasa berperilaku bersahaja dan fleksibel, tidak terpaku dengan aturan-aturan formal. ${ }^{1}$

Seorang Tuan Guru seharusnya berada ditengah-tengah umat, sehingga secara langsung dapat mengetahui permasalah-permasalahan yang dihadapi umatnya, untuk memberikan solusi alternatif. Bagi Tuan Guru yang menduduki jabatan eksekutif hal itu tentu tidak akan dapat dijalankannya dengan mudah. Kekuatan Tuan Guru secara tradisional dan formal dalam pemerintahan jika disinergikan dengan mengedepankan kepentingan umat, akan melahirkan kebijakan dan keputusan yang membawa kepada kemakmuran rakyat, tetapi Tuan Guru adalah seorang individu yang memiliki basis umat tersendiri, tidak terbiasa kerja kolektif, dan cenderung sudah terbiasa mendapat previlage dalam masyarakat, sehingga antara Tuan Guru yang satu dengan yang lainnya acapkali terjadi ketidakselarasan jalan

Perilaku politik Tuan Guru sangat khas, karena memiliki legitimasi yang kuat dibidang keagamaan, dan sosial sekaligus. Dalam menjalankan kepemimpinannya, Tuan Guru menggunakan wewenangnya berdasarkan kharisma (charismatic authority) yang dimilikinya, yang menurut Max Weber adalah suatu kemampuan khusus yang ada pada diri seseorang dan merupakan anugerah dari Tuhan. Dengan wewenang kharismatik ini, Tuan Guru diakui sebagai sosok yang memiliki kemampuan memimpin yang berada diatas kemampuan ummat yang dipimpinnya. Kharisma ini terwujud dari kepercayaan dan pemujaan terhadap Tuan Guru. Dasar dari wewenang kharismatik ini bukanlah terletak pada suatu aturan (hukum). Namun bersumber dari pribadi Tuan Guru yang bersangkutan. Kharisma ini semakin meningkat sejalan dengan kemampuan Tuan Guru untuk membuktikan manfaatnya bagi masyarakat. Wewenang kharismatis diatas dapat berkurang atau hilang sama sekali jika ternyata individu yang bersangkutan melakukan kesalahan-kesalahan yang merugikan masyarakat sehingga kepercayaan masyarakat terhadapnya semakin berkurang. ${ }^{2}$

\footnotetext{
1 Hiroko Horikoshi, Kiai dan Perubahan Sosial (Jakarta: LP3ES, 1997), 88.

2 Miriam Budiharjo, “Konsep Kekuasaan: Tinjauan Kepustakaan”, dalam Miriam
} 
Disamping wewenang kharismatik yang dimilikinya, Tuan Guru memiliki wewenang tradisional (traditional authority). Weber menyebutkan wewenang ini sebagai wewenang yang dimiliki seseorang atau sekelompok orang yang telah lama memegang kekuasaan dalam suatu masyarakat. Wewenang ini bukanlah disebabkan karena kelebihankelebihan dan kekhususan yang dimiliki seseorang, namun karena ia telah lama memegang kekuasaan sehingga masyarakat sangat mempercayainya dan mendarah daging dalam kehidupannya. Beragam perilaku politik Tuan Guru tersebut merupakan pilihan dan jalan yang ditempuh untuk ikut berperan serta dalam pembangunan umat manusia, karena sebaikbaik manusia adalah orang yang paling baik moralnya dan mampu memberi manfaat kepada orang lain

Tuan Guru adalah pemimpin, bukan hanya pemimpin dilembaga yang dia bina, akan tetapi Tuan Guru adalah pemimpin dalam masyarakat, kepemimpinan Tuan Guru disebabkan karena kaektifan Tuan Guru ditengah-tengah masyarakat, dimana ada acara kegiatan kemasyarakatan atau kegiatan keummatan disanalah Tuan Guru ada dan kebaradaan Tuan Guru pada acara tersebut sangat ditunggu-tunggu masyarakat. Karena hubungan silaturrahmi dan interakasi Tuan Guru dengan masyarakat yang intens tersebut secara alami masyarakat menjadikan sosok Tuan Guru sebagai leader dan tokoh panutan dalam masyarakat Lombok, sebagaimana dalam the treath teory disebutkan bahwa pemimpin yang berasal dari orang biasa dan pada awalnya tidak memiliki kemampuan apa-apa dalam hal memimpin, tetapi karena interaksinya yang inten dengan lingkungan akhirnya ia bisa tampil sebagai sosok pemimpin yang handal dan bisa mempengaruhi orang lain atau masyarakat yang dipimpinnya untuk mencapai tujuan yang telah ditetapkan. ${ }^{3}$

Interaksi Tuan Guru ditengah-tengah masyarakat mempunyai pengaruh yang kuat sehingga Tuan Guru bukan hanya sosok ulama atau orang yang mempunyai kemampuan dalam ilmu-ilmu agama, akan tetapi Tuan

Budiharjo (ed.), Aneka Pemikiran tentang Kuasa dan Wibawa (Jakarta: Sinar Harapan, 2004), 88.

${ }^{3}$ Pradjarta Dirdjosanjoto, Memelihara Umat: Kiai Pesantren-Kiai Langgar Di Jawa (Yogyakarta: LkiS, 2009), 66. 
Guru juga merupakan umaro'(pemimpin ) non formal dalam masyarakat. Sebagaimana dalam teori prilaku atau Behaviorist Theories disebutkan bahwa teori ini pada intinya beranggapan bahwa seorang akan bisa menjadi pemimpin apabila bisa menggabungkan antara orientasi tugas (task oriented) dan orientasi pada hubungan (relation oriented). ${ }^{4}$

Peran Tuan Guru di Lombok sebagai tokoh panutan berdiri diatas semua golongan, mereka tidak memihak pada satu kekuatan golongan tertentu. Peran kepemimpinan Tuan Guru di masyarakat Lombok akan sirna manakala Tuan Guru sudah mengkubu pada salah satu kekuatan dalam satu golongan. Pengaruh kharisma Tuan Guru di masyarakat menjadi tidak bermakna ketika otoritasnya menyimpang dari apa yang seharusnya ia lakukan terhadap masyarakat. Seorang Tuan Guru yang dahulunya merupakan tokoh kharismatik, sangat dihormati, menjadi panutan masyarakat, eksistensinya akan menjadi turun layaknya warga masyarakat biasa, ketika menanggalkan sifat zuhud dan berubah menjadi seorang yang materialis. Ketika seorang Tuan Guru melakukan sesuatu yang menyimpang yang tidak sesuai dengan norma dan ajaran agama, maka masyarakat akan menjauh darinya.

Dalam hal ini Tugas sebagai Tuan Guru yang merupakan abdi masyarakat, intensitas Tuan Guru bergaul dengan masyarakat sangat tinggi, dan kepercayaan masyasrakat kepada Tuan Guru juga tinggi, sehingga pengaruh tugas atau amanah masyarat yang diemban oleh Tuan Guru telah menciptkan orientasi hubungan dan pengaruh Tuan Guru ditengahtengah masyarakat sangat kuat, sehinga Tuan Guru bukan hanya sebagai guru agama, akan tetapi Tuan guru adalah sosok leader dalam masyarakat.

Sebagaimana yang penulis temukan dilapangan bahwa Tuan Guru meupakan orang yang di tuakan, sehingga dalam setiap acara-acara keagamaan maupun acara-acara sosial kemasyarakatan sebelum Tuan Guru hadir dalam acara tersebut maka masyarakat merasa sungkan untuk memulai acara tersebut sebab harus menunggu kehadiran Tuan Guru terlebih dahulu, sehingga nilai-nilai Tuan Guru dimasyarakat sangat tinggi, oleh sebab itu pengaruh yang tinggi Tuan Guru terhadap masyarakat inilah menurut analisa penulis banyak partai-partai politik yang

${ }^{4}$ Sartono Kartodirdjo (ed), Elit dalam Perspektif Sejarah (Jakarta: LP3ES 2013), 94. 
ingin meminang Tuan Guru sebagai wakil partai untuk djadikan calon wakil rakyat. ${ }^{5}$

Melihat kedudukan dan peran Tuan Guru yang mulia tersebut yang dianggap sebagai guru bangsa dalam masyarakat Lombok dan senantiasa mengajar umat sepanjang hidupnya tanpa mengharap upah, sebagian kalangan berpendapat bahwa seorang Tuan Guru seharusnya cukup berperan sebagai pengayom umat, penjaga moral bangsa terutama dalam kehidupan beragama, tanpa terlibat dalam kegiatan politik, karena kehidupan politik seringkali diwarnai oleh intrik dan permainan kotor yang berlawanan dengan tabiat moral seorang Tuan Guru, akan tetapi karna keinginan Tuan Guru dalam memajukan lembaga pendidikan yang di kelolanya, maka ada beberapa Tuan Guru di Lombok bersentuhan dengan politik bahkan ada yang menjadi pengurus dalam partai politik dan mendapatkan kekuasaan dengan motor politik tersebut yang tidak lain tujuannya adalah agar dapat memajukan lembaga pendidikan yang ia kelola, seperti hasil penelitian Horikoshi Tuan Guru sangat berperan aktif dalam proses politik, dengan berbagai varian dan bentuk peranan yang beragam. ${ }^{6}$

Akhirnya realitas posisi Tuan Guru di Lombok selalu dihadapkan pada kenyataan yang melingkupinya, yaitu mempunyai peranan ganda, seorang Tuan Guru di Lombok disamping sebagai tokoh agama dan sekaligus juga sebagai tokoh politik. Dan secara historis peran ini telah dimainkannya dengan amat baik oleh Tuan Guru sejak masa awal Islam berkembang di Indonesia hingga saat ini. ${ }^{7}$ Meskipun demikian statemen lain mengatakan bahwa tidak selayaknya seorang Tuan Guru ikut memperebutkan kekuasaan, akan tetapi berperan sebagai pengawal moral bangsa, mengawasi dan menasehati, dengan tetap menjaga jarak dengan penguasa. Terlepas dari pendapat pro dan kontra mengenai kedudukan

5 Tuan Guru Haji Mukhlis Ibrahim, Wawancara, Dalam Acara Peringatan Maulid Nabi Besar Muhammad SAW, Masjid Pondok Pesantren Islahudini Kediri Lombok Barat, 18 Desember 2019.

${ }^{6}$ Hiroko Horikoshi, Tuan Guru dan Perubahan Sosial (Jakarta: P3M. 1987), 12.

7 Pradjarta Dirdjosanjoto, Memelihara Umat; Kiai Pesantren-Kiai Langgar Di Jawa (Yogyakarta:LKIS 1999), 197. 
dan peran Tuan Guru dalam percaturan politik, sejarah telah merekam kenyataan empiris yang membuktikan bahwa kedudukan dan peran Tuan Guru amat strategis dan signifikan dalam kehidupan masyarakat, sehingga banyak ditemui keterlibatan Tuan Guru dalam politik meskipun bentuk dan tingkat keterlibatannya berbeda-beda. Ada yang bergandeng tangan dengan penguasa, ada yang bersikap resisten dengan membuat gerakan perlawanan, ada pula yang menjaga jarak dengan tetap memposisikan diri sebagai pengayom umat.Tuan Guru di Lombok khususnya di daerahdaerah pedesaan, merupakan elit lokal yang berakar dan berpengaruh kuat dalam kehidupan masyarakat, besarnya pengaruh karna tersebut karna dianggap sebagai seorang ulama lokal terhadap penduduk di Lombok. Menurut Bouwsma, pengaruh ini sudah ada sejak zaman kerajaankerajaan, mereka tidak hanya sebagai pemimpin keagamaan melainkan juga pemimpin secara informal, karena kedudukan dan peran Tuan Guru lebih terhormat dimata masyarakat dibanding pemimpin formal (aparat pemerintah). ${ }^{8}$

Ketaatan masyarakat terhadap Tuan Guru melebihi kepatuhan mereka kepada pemerintah, sehingga secara kultural posisi Tuan Guru amat kuat dan akan selalu bersinggungan dengan problem umat secara global termasuk dengan urusan politik. Di lihat dari sejarah perpolitikan di Indonesia, pertautan ulama dengan politik mengalami pasang surut atau berubah-ubah dari masa ke masa, di pulau Jawa, pada zaman walisongo para wali mem-back-up penuh pemerintahan Islam, bahkan walisongolah yang merumuskan dan membentuk kerajaan Islam pertama di Demak, keberadaan walisongo saat itu sangat politis. Pada zaman penjajahan Belanda Tuan Guru yang berpolitik atau mengadakan perlawanan terhadap Belanda di tangkap dan dipenjarakan, sehingga banyak Tuan Guru yang lebih aktif berada di lingkungan pesantren dan menjalani kehidupan sufi daripada aktif di dunia politik. Meskipun demikian sebagian Tuan Guru masih tetap aktif dalam pergerakan menentang penjajah meskipun secara sembunyi-sembunyi.

\footnotetext{
8 Sartono Kartodirdjo, Elite dalam Perspektif Sejarah (Jakarta: LP3ES 1983), 587.
} 
Secara keilmuan, banyak para Tuan Guru di Lombok yang bukan mempunyai latar belakang keilmuan baik dibidang pemerintahan, kesehatan, psikologi, administrasi maupun dalam bidang ilmu komunikasi, akan tetapi secara praktis Tuan Guru di masyarakat Lombok mempunyai peranan yang beragam seperti Tuan Guru sebagai konsultan, Tuan Guru sebagai pemimpin masyarakat dan Tuan Guru sebagai administrator dalam lembaga pendidikan dan dalam kemasyarakatan. Tuan Guru dalam masyarakat Lombok dibagi menjadi dua macam yaitu, Tuan Guru Statis Tradisional dan Tuan Guru Dinamis Rasional

Tuan Guru statis tradisional adalah Tuan Guru yang tetap memegang dan mempertahankan tradisi-tradisi lama seperti selalu menggunakan sarung, kopiah putih dan surban dalam setiap kali mengikuti acara dan kegiatan baik formal maupun non formal, Tuan Guru ini juga mempunyai ciri khas dalam menggunakan surban. Tuan Guru seperti ini biasanya dikawal oleh santri atau muridnya dan jarang menggunakan media-media komunikasi seperti handphone dan jarang tampil dalam acara-acara formal pemerintahan. Berbeda halnya dengan Tuan Guru dinamis rasional, Tuan Guru dinamis rasional sudah mengalami perkembangan sesuai dengan zamannya, Tuan Guru dinamis rasional sangat akrab dengan pemerintah dan sangat dengan tekhnologi dan kemajuan. Tuan Guru statis tradisional mempunyai peranan yang kuat di masyarakat pedesaan dan masyarakat dan masyarakat perkotaan. Tuan Guru ini mempunyai kharisma sangat tinggi di masyarakatnya bahkan ada diantara Tuan Guru dari golongan ini yang dianggap keramat oleh masyarakat. Banyak masyarakat yang datang kepadanya untuk meminta petunjuk dan doanya bahkan nasehatnya. Tuan Guru ini tidak mau mendatangi pemerintah tapi didatangi pemerintah. Tuan Guru statis tradisional ini enggan meminta bantuan pemerintah tapi pemerintah yang datang berkunjung ke kediamannnya. Dalam mengelola dan mempimpin pondok pesantren Tuan Guru ini tidak menggunakan manajemen dan administrasi pembukuan tapi kejujuran dan kepercayaan yang dijadikan landasan administrasinya sehingga sumbangan maupun bantuan pemerintah dan masyarakat kepadanya tidak pernah menggunakan catatan berupa bukti kwitansi ataupun bukti fisik sumbangan karena kharisma dan kepercayaan yang diberikan masyarakat kepadanya sangat tinggi. Sedikit berbeda dengan Tuan Guru dinamis 
rasional, Tuan Guru ini dekat dengan pemerintah bahkan ada yang sebagai pemerintah, tujuan Tuan Guru ini terjun dalam pemerintahan dan birokrasi pemerintahan adalah dalam rangka mengawal moral dan ubudiyah, peranan Tuan Guru ini sangat tinggi jika dia dapat mewakili umat dan tetap menjadi suri tauladan umat. Tuan Guru di Lombok adalah merupakan sosok yang memberikan power dan sugesti dalam setiap sendi kehidupan sebab tanpa kehadiran Tuan Guru dalam setiap acara maka acara tersebut di anggap kurang barokah sebab doa-doa dan nasehat yang di ucapkan oleh Tuan Guru dapat memberikan sugesti dan spirit bagi masyarakat, masyarakat meyakini doa dan sugesti yang di berikan Tuan Guru mempunyai pengaruh yang kuat dibandingkan doa dan sugesti dari yang lainnya. Peranan Tuan Guru selain sebagai pemimpin lembaga pendidikan di pondok pesantrennya, Tuan Guru juga di anggap sebagai pemimpin dalam masyarakat Lombok walaupun kepemimpinan Tuan Guru tersebut belum diakui secara formal dalam pemerintahan, dalam setiap acara-acara kemasyarakatan kehadiran Tuan Guru sangat dinantinantikan oleh warga sehingga dalam tradisi kemasyarakatan Lombok, Tuan Guru merupakan pemimpin non formal yang masa kepemimpinannya tidak mempunyai batas waktu-waktu tertentu dan perananaya dalam pemerintahan tidak terikat dengan jabatan-jabatan tertentu, artinnya selama Tuan Guru tersebut bisa mencerminkan akhlakul karimah dan suri tauladan dalam masyarakat maka selama itu pula Tuan Guru akan dijadikan panutan dalam masyarakat. Tuan Guru di masyarakat Lombok Lombokjuga sebagai konsultan, banyak warga masyarakat yang datang berkonsultasi pada Tuan Guru tentang kapan hari pantasnya dilakukan akad pernikahan, begitu juga dengan hal-hal lainnya seperti warga yang datang berkonsultasi kepada Tuan Guru bagaimana cara membina rumah tangga yang mawaddah sakinah dan rahmah, bahkan Tuan Guru juga menjadi penasehat untuk menengahi rumah tangga yang hampir mengalami perceraian. ${ }^{9}$

\footnotetext{
9 Tuan Guru Haji Hasanain Juwaini, Pimpinan Pondok Pesantren Nurul Haromain
} 


\section{Peranan Sosial Politik Tuan Guru Dalam Memajukan Pendidikan Islam}

Perjuangan politik Tuan Guru bukan hanya untuk kepentingan kepemimpinan dan kekuasaan saja akan tetapi juga untuk kepentingan kemajuan pondok pesantren yang dipimpinnya, sehingga keberadaan Tuan Guru di pentas politik adalah dalam upaya untuk kemajuan pendidikan Islam di pondok pesantren bukan hanya pada pondok pesantren yang dia miliki akan tetapi pada lembaga-lembaga pendidikan Islam lainnya.

Kapasitas Tuan Guru di bidang politik terhadap perkembangan pendidikan di harapkan oleh masyarakat dan santri disekitarnya dapat memajukan dunia pendidikan sehingga persentuhan Tuan Guru dengan politik serta kekuasaan dapat berimbas pada kemajuan lembaga yang di kelolanya baik kemajuan fisik lembaga tersebut ataupun peningkatan kwalitas pendidikan dalam lembaga tersebut. Keberhasilan atau kegagalan sebuah lembaga pendidikan akan sangat ditentukan oleh tingkat keteguhan dan kesungguhan para pengasuhnya yaitu Tuan Guru dalam mengembangkan lembaga yang dipimpinnya, karena itu sebenarnya tidaklah terlalu berlebihan jika ada banyak pengambat menilai bahwa pesantren itu merupakan persoalan enterprise para pengasuhnya, konsep seperti ini hendaklah jangan dipahami dalam konteks konvensional yang biasanya berkaitan erat dengan kepemilikan pribadi, akan tetapi hendaknya dipahami dalam konteks sosiologis, dalam konteks seperti ini, maka para pengasuh tersebut sejak awal memulai, mengembangkan dan menjaga dinamika pendidikan di pesantren, sehingga wajar sekali demikian ketatnya hubungan antara Tuan Guru dengan pesantren yang di pimpinnya, sehingga tidaklah sedikit diantara mereka yang memehami itu sebagai ibadah dalam pengertian yang luas walaupun memang dalam kerangka administrasi, pondok pesantren sering tidak selalu dikaitkan dengan adanya instituisi badan wakaf, para anggota badan wakaf itulah yang secara kolektif menentukan perjalanan pesantren, akan tetai pengaturan demikian itu lebih dimaksudkan untuk menjamin tingkat sustainability pesantren, khususnya jika para pendiri dan pengasuhnya

Narmada, Wawancara, Lombok Barat, 18 November 2019. 
sudah tidak ada lagi, dalam situasi biasa, maka hidup matinya pesantren berada pada tangan pengasuhnya atau pendirinya, dalam konteks seperti inilah personal enterprise hendaknya dipahami. Subkultur pesantren yang dibangun oleh Tuan Guru dan santri dengan ciri- ciri ekslusif, fanatisme dan esoteris adalah sebagai suatu uapay dalam rangka menjaga tradisitradisi keagamaan dari pengaruh eksternal, walaupun sebenarnya yang harus mendapatkan perhatian adalah dari segi hubungan antara subkultur pesantren dengan pengaruh perubahan sosial

Perkembangan masing-masing pesantren memiliki akselerasi yang berbeda, dan gejala ini dapat diketahui dari faktor sosial budaya yang mempengaruhi masyarakat sekitar pondok pesantren itu sendiri, perbedaan sosial budaya masyarakat menentukan tujuan berdirinya lembaga pesantren, sehingga dalam perkembangan selanjutnya masingmasing pondok pesantren memiliki arah yang berbeda, sesuai dengan tingkat kebutuhan masyarakat sekitar. Pendidikan Islam di pondok pesantren memiliki tujuan keagamaan sesuai dengan pribadi dari Tuan Guru pendiri pesantren tersebut, sedangkan methode pengajarannya dan materi kitab yang diajarkan ditentukan sejauh mana kualitas yang dimiliki oleh kiai dan yang dipraktekan sehari-hari dalam kehidupannya. ${ }^{10}$

Pendidikan Islam di pesantren memiliki misi yang sarat dengan muatan-muatan keagamaan, bahkan seorang Tuan Guru menjelaskan bahwa pesantren adalah sebagai suatu lading amal ibadah untuk kehidupan akhirat, tujuan yang tidak dibuktikan dengan papan statistik dan tertulis adalah untuk menghidari sikap ria, corak kelembagaan pondok pesantren serta kepemimpinan yang dilakukan era sekarang tidak lain merupakan kosekuensi logis dari perjalanan pesantren dalam periode sebelumnya, perubahan dan penyesuaian yang terjadi dalam dunia pesantren menunjukan bahwa visi, misi dan kepemimpinan kiai mampu menyesuaikan diri dengan perkembangan kehidupan masyarakat serta sistem pendidikan nasional, hal ini merupakan suatu bukti bahwa peantren dapat melakukan pembaharuan sistem pendidikannya yang telah diterpkan selama bertahun-tahun, bahkan yang lebih luwes lagi kiai

\footnotetext{
${ }^{10}$ Zamakhsyari Dhofier, Tradisi Pesantren: Studi Tentang Pandangan Hidup Kiai (Jakarta: LP3ES, 1992), 68.
} 
bersedia meninjau kembali pemahaman keagamaan termasuk bidangsosial serta mencari pola baru dalam kaderisai kepemimpinan guna mempersiapkan regenerasi kepemimpinan pondok pesantren.

Visi yang dikembangkan oleh pesantren akan berbeda dengan lemk baga pendidikan lainnya,baik lembaga pendidikan non formal terlebih lembaga pendidikan formal, pesantren adalah suatu lembaga pendidikan yang tidak mencetak pegawai yang mau diperintah oleh orang lain, akan tetapi lembaga pendidikan yang mencetak majikan (paling tidak) untuk dirinya sendiri, bahkan lembaga yang mampu mencetak orangorang yang berani hidup mandiri

Hal ini dibuktikan dengan mutu lulusan yang sudah sekian lama mengenyam pendidikan di pesantren lalu terjun kemasyarakat dan berbaur untuk hidup dala masyarakat bahkan mereka cenderung menjadi pionir yang selalu berusaha meronovasi dan menata kehidupan keagamaannya yang semakin sarat dengan tuntutan perubahan zaman.

Dikalangan umat Islam sendiri nampaknya pesantren telah dianggap sebagai model institusi pendidikan yang memiliki keunggulan, baik dari segi aspek tradisi keilmuannya, maupun pengakuan masyarakat akan keberadaannya yang oleh Martin Van Bruinessen menilai sebagai salah satu tradisi agung maupun sisi transmisi dan internalisasi moralitas umat Islam. ${ }^{11}$ Akan tetapi disamping sisi-sisi kebaikan pondok pesantren dengan segala komunitasnya, namun perlu dikemukakan pula beberapa tantangan kedepan yang dihadapi oleh pondok pesantren dewasa ini, tantangan yang dialami oleh lembaga ini menurut para ahli semakin hari semakin komplek terumata sejaln dengan maju pesatnya pertumbuhan ilmu pengetahuan dan teknologi, tantangan ini menyebabkan terjadinya pergeseran nilai yang berkaitan dengan manajemen pondok pesantren. Ada beberapa indikator pergeseran nilai yang dialami oleh pondok pesantren, diantarannya adalah:

1. Tuan Guru bukan lagi satu-satunya sumber belajar, dengan semakin beraneka ragamnya sumber belajar baru, maka semakin tinggi pula dinamika komunikasi antara sistem pendidikan pondok pesantren

${ }^{11}$ Martin van Bruinessen, Rakyat Kecil, Islam dan Politik (Yogyakarta: Bentang Budaya, 1998), 76. 
dengan sistem yang lain, santri dapat belajar dari berbagai sumber, namun kondisi semacam ini tidak segera menggeser kedudukan Tuan Guru sebagai tokoh kunci yang menentukan corak pendidikan pesantren.

2. Sering dengan pergeseran nilai, maka kebanyakan santri saat ini membutuhkan ijazah dan penguasaan bidang ketrampilan-ketrampilan yang jelas agar dapat mengantarkannya untuk menguasai dan memasuki lapangan kehidupan bru, sebab dalam kehidupan modern kita tidak hanya cukup dengan berbekal moral yang baik, tetapi perlu dilengkapi dengan skil yang relevan dengan sinergis dan kebutuhan dunia kerja.

\section{Penutup}

Dalam penutup ini, peneliti berusaha untuk memberikan point penting dari hasil penelitian, yaitu berupa kesimpulan yang dapat peneliti rangkum sebagai berikut:

1. Tuan Guru di Lombok memiliki kedudukan dan peranan yang sangat luas, tidak hanya pada aspek keagamaan, melainkan juga pada bidang sosial, ekonomi dan politik. Tuan Guru memiliki multi peran di masyarakat, dengan kharisma dan otoritas yang dimilikinya Tuan Guru dapat mempengaruhi tindakan dan pilihan politik pengikutnya, dan keluarganya mendapatkan previlage dari masyarakat, tidak hanya mendasarkan pada kedalaman ilmu dan ketinggian moral, tetapi juga karena faktor nasab (keturunan), warisan dari keluarganya.

2. Partisipasi politik Tuan Guru mengalami pasang surut sesuai dengan konteks zamannya, tetapi pada era reformasi tingkat keterlibatan Tuan Guru sangat tinggi, pintu Tuan Guru untuk terjun di dunia politik terbuka lebar, karena partai politik membutuhkan mereka dan Tuan Guru juga membutuhkan wadah untuk menyalurkan aspirasinya. Terdapat tiga golongan partisipasi politik Tuan Guru, yaitu; Tuan Guru yang secara langsung menjabat sebagai pengurus partai politik, Tuan Guru yang berafiliasi kepada salah satu partai politik, tetapi tidak terlibat secara langsung dalam aktifitas kepartaian, dan Tuan 
Guru independen, yang tidak memberikan dukungan kepada salah satu partai, tetapi aktif membina dan memberikan pengajaran kepada masyarakat.

\section{Daitar pustaka}

Anoraga, Pandji. Psikologi Kepemimpinan, Cet. 3; Jakarta: Rineka Cipta, 2011.

Arfani, Noer Riza. Governance dan Pengelolaan Konflik, Makalah disampaikan pada "Worshop Analisis Kebijakan Publik, Yogyakarta: Magister Studi Kebijakan UGM, 2015.

Azra, Azyumardi. Pendidikan Islam: Tradisi dan Modernisasi Menuju Milenium Baru, Logos Wacana Ilmu, 2009.

Bennis, Warren G. Organizational Development, Its Nature, Origins and Prospects, Addison Wesley, Reading MassBertrand, 1999. L. Alvin. Social Organization: A General Systems and Role Theory Perspective, Louisiana State University, Baton Rouge, 1994.

Blau, M Peter dan M. W. Meyer. Birokrasi Masyarakat Modern, Edisi Kedua, Cetakan Pertama, Alih Bahasa Gary Rachman Jusuf, Jakarta: UI-Press, 1997.

Budiharjo, Miriam. "Konsep Kekuasaan: Tinjauan Kepustakaan", dalam Miriam Budiharjo (ed.), Aneka Pemikiran tentang Kuasa dan Wibawa. Jakarta: Sinar Harapan, 2008.

Bungin, Burhan. Penelitian Kualitatif: Komunikasi, Ekonomi, dan Kebijakan Publik Serta Ilmu-Ilmu Sosial Lainnya, Ed. 1, Cet. 4; Jakarta: Kencana, 2016.

Bradford, D. Kevin. dkk. Managing Conflict to Improve the Efectiveness of Ad-Hoc Marketing Teams, Departement of Marketing, University of Notre Dame, Kevin.Bradford.11@nd.edu. diakses 27 Juli 2019.

Bruinessen, Martin van. Rakyat Kecil, Islam dan Politik, Yogyakarta: Bentang Budaya, 2008. 
Departemen Pendidikan Dan Kebudayaan. Kamus Besar Bahasa Indonesaia, Jakarta: Balai Pustaka, 2002.

Dhofier, Zamakhsyari. Tradisi Pesantren: Studi Tentang Pandangan Hidup Kyai, Lembaga Penelitian, Pendidikan, dan Penerangan Ekonomi dan Sosial, 2009.

Dirdjosanjoto, Pradjarta. Memelihara Umat; Kiai Pesantren-Kiai Langgar di Jawa. Yogyakarta: LKIS, 2012.

Dwiyanto, Agus. dkk. Konflik di Era Otonomi Daerah dalam "Reformasi Tata Pemerintahan dan Otonomi Daerah”, PSKK-UGM, Yogyakarta. Jakarta: LP3ES, 2009.

Faridl, Miftah. Peran Persepsi Teologis dalam Perilaku Sosial Politik Kiai, Disertasi pada IAIN Syarif Hidayatullah, Jakarta, 2000.

Horikoshi, Hiroko. Kiai dan Perubahan Sosial, Jakarta: LP3ES, 2017.

Kartodirdjo, Sartono. Elite dalam Perspektif Sejarah, Jakarta: LP3ES, 2009.

Morris and Seeman. "A General Framework for the Study of Leadership," in Paul F. Lazerfeld and Morris Rosenberg (ed), The Language of Social Reasearch. Illionis: The Free Press Publishers, 1999.

Sukamto, Purnomo. Pesantren Jalan Menuju Perjuangan, Bandung: Pustaka Jaya, 2015. 